\title{
Fruit Trees and Bushes as a Biodiversity Element in the "Górażdże" Quarry Reclaimed Areas
}

\author{
Katarzyna Łuczak ${ }^{1}$, Grzegorz Kusza ${ }^{*}$, Daria Słonina² ${ }^{2}$ Krystyna Borecka ${ }^{1}$ \\ 1 Institute of Environmental Protection and Development, University of Opole, Oleska 22, 45-052 Opole, Poland \\ 2 Wroclaw University of Science and Technology, Bolesława Prusa 53/55, 50-317 Wrocław, Poland \\ * Corresponding author's e-mail: Grzegrz.Kusza@uni.opole.pl
}

\begin{abstract}
The assumption of biological land reclamation in the forest direction is to introduce trees and shrubs on the reclaimed area so as to bring it as close as possible to the natural state based on the species characteristic for forest communities. While assessing the concept of biodiversity resulting from the naturalistic approach to the forest as a timeless good, it is necessary to take into account the diversity of plantings used and their multifunctionality. One of the functions is to designate crops for utility purposes, by creating a natural undergrowth, birdhouses, forest fringe plantings and enclaves of edible fruit plants. As part of the research, implementing the biodiversity of midforest plantings in the post-mining areas of the "Górażdże" Limestone Mine (Opolskie Voivodeship), the focus was put on the natural renewal of the tree stand with the admixture of fruiting plants. The application of fruit tree and shrub plantings on relatively small areas allowed the creation of areas of high biodiversity on the recultivated monoculture grounds. The results of the research revealed a relatively high efficiency of the planted trees and shrubs regardless of the existing habitat conditions. The following species had the best health status throughout the vegetation period: apple-tree, common pear, briar-rose, blackthorn and singleseed hawthorn. The use of fruit tree and shrub plantings will contribute, on the one hand, to reducing the costs of reclamation, which is a measurable effect for the mine manager, and strengthening the ecological potential of the new biotope created under the conditions of strong anthropogenic pressure on the other.
\end{abstract}

Keywords: opencast limestone mine, internal dump, forest reclamation, biocenotic species, health condition of trees

\section{INTRODUCTION}

The constantly growing demand for mineral resources causes expansive exploitation of deposits, which results in permanent changes to many areas. Drastic changes occur in landscape, natural environment and, most of all, the land morphology [Baran and Turski 1996; Karczewska 2008]. The radical changes result, among others, from changing areas into open pits as well as the created external dumps. The organised activities aiming at reclamation of post-mining areas were initiated already in the mid-1950s. The pioneering form of land reclamation was afforestation, which currently covers over $60 \%$ of all post-mining areas [Krzaklewski 2017; Dulewski and Madej 2002; Strzyszcz and Harabin 2004]. The development of reclamation methods and techniques allowed to restore areas to use but also to create entirely new ecosystems. Afforestation or water methods are most frequently used for the post lime quarries areas. While using afforestation, it is important to recreate soils, thanks to the technical and biological reclamation method. Its first stage is based on the melioration/improvement of chemical and physical characteristics of the soil [Strzyszcz 2003; Strzyszcz and Harabin 2004; Pietrzykowski 2008]. The next stage involves shaping the selected soil generating processes, by using trees. This results in the emergence of a productive soil layer, which includes the main component, i.e. humus.

The important element, which conditions the biological reclamation is the appropriate selection of tree and bush types, taking into consideration the existing settlement area and microclimate. While assessing the concept of biodiversity, 
which results from the naturalistic approach to the forest as a timeless benefit, one should also emphasise both the importance of plantings as the future timber source but also an important biocenotic role. The main assumption of biological reclamation by afforestation is to introduce trees and bushes to an area in the way most closely resembling a natural forest ecosystem, based on the existing habitat conditions. The new approach in the process of selection of the types of plants introduced during afforestation is the use of fruitbearing trees and bushes. The introduced biocenotic types shall have a positive impact on the animal fodder accessibility, mainly birds and insects, considerably increasing the biocenotic importance of the reclaimed areas [Strzyszcz 1995; Krzaklewski and Pietrzykowski 2007].

The main aim of the carried out research was an attempt to increase the flora diversity in the after-closure areas of the "Górażdże" limestone quarry, by introducing fruit-bearing trees and bushes within a biological reclamation project.

\section{THE OBJECT OF RESEARCH}

The "Górażdże" limestone quarry is located in the north of Opole province (Poland); 90\% of the deposit area is located in the commune of Gogolin. The quarry lies in the area of the state forests holding held by the forest district Strzelce Opolskie and the lands of Górażdże village. Three experimental fields with an average area of 20 ares, situated in external dumps with various habitat conditions, were selected for the study [Mapa Sozologiczna Polski 1996]. Field I was located in a fresh dump made during technical reclamation work, and there was no turf. Field II was established in the older part of the dump ( 3 years old) with $60 \%$ turf made up mainly of dicotyledonous and monocotyledonous plants, whereas field III was located on the 5 years old dump with over $70 \%$ of turf.

\section{MATERIALS AND METHODS}

Planting of the selected fruit-bearing plants was carried out in the set out fields in March 2016, in small, mixed clusters, taking into consideration the aspect of plants growth and their competition across species. Experimental fields had the same species composition: sloe Prunus spinosa, rosehip
Rosa canina, cherry plum Prunus cerasifera, buckthorn Rhamnus catharicus, rowan Sorbus aucuparia, black elder Sambucus nigra, single-seeded hawthorn Crataegus monogyna, common hazel Corylus avellana, wild apple Malus domestica, common pear Pyrus communis. The proposed tree and bush species are characterised by low environmental requirements, they are mainly photophilous, grow well in dry or moderately moist clay, stone or sandy soils; they are also resistant to droughts and frost. The main body of the research included the assessment of the suitability of plantings and the condition of trees and bushes after 1 , 2, 3 and 5 months from the planting date.

Additionally, an analysis of the selected physical and chemical characteristics of experimental fields was carried out. The soil samples taken in the spring of 2016 from the depth of $0-30 \mathrm{~cm}$ were brought to air-dry condition, homogenised in a mortar and passed through a $2.0 \mathrm{~mm}$ sieve. The material was separated into skeletal (grains with diameter over $2 \mathrm{~mm}$ ) and coarse sand (grains with diameter 1.0-2.0 $\mathrm{mm}$ ).

The Soil samples were taken in the summer of 2016 from the depths of $0-10$ and $10-30 \mathrm{~cm}$. The samples were dried, homogenized and then sieved. The samples were also divided into a few sections: elements larger than $2 \mathrm{~mm}$, elements sized $1.0-2.0 \mathrm{~mm}$. In the section where elements were smaller than $1.0 \mathrm{~mm}$, aerometric Casagrand's method with Proszynski's modification was used to determine the granulometric composition of the sample. The fractions larger than $0.1 \mathrm{~mm}$ were determined granulometirically by using sieve and water method. The following chemical characteristics were also determined: (1) saltiness by conductometric method based on electrolytic conductivity of water-soil mixture in weight proportion soil/water 1:5; (2) $\mathrm{pH}$ in $\mathrm{H}_{2} \mathrm{O}$ and $\mathrm{KCl}$ by potentiometer (weight proportion soil/water $1: 2.5$ ); (3) total organic carbon spectrophotometrically using the Analyzer Multi N / C 3100 with a combustion furnace HT 1300; (4) absorbable forms of potassium, phosphorus and magnesium by the methods of Egner-Riehm and Schachtschabel; (5) nitrogen content using the Kjeldahl method.

\section{RESULTS}

The granulometric composition defines the degree of fragmentation of the soil mass, which 
considerably influences the soils characteristics. The analysis of granulometric structure of the samples taken from experimental fields (according to the PTG 2009 criteria)[Particle size distribution and textural classes of soils and mineral materials - classification of Polish Society of Soil Science 2008], showed that initial soils are built by strongly skeletal forms, in particular in field I and II (Table 1). Mineral clay forms were present in all experimental surfaces: light (field II), sandy-loam (field III) and normal (field I). This confirms the occurrence of relatively difficult settling conditions for the development and growth of root systems, in particular in field I.

The analysis results of the material taken from the studied surfaces show differentiated content of organic carbon. In field I, the content of total organic carbon was $0.66 \%$; this signifies a potential lack of the possibility of, among others, microelements accumulation as well as small capacity of the sorption complex. The TOC content increases in proportion to the size of the turf generating plant cover, in field II and III 1.69\% and $2.11 \%$, respectively. Additionally, the high proportion of $\mathrm{C}: \mathrm{N}$, amounting in all cases to over $35: 1$, illustrates the degraded character of the soil in the reclaimed internal dump of the quarry.

The reaction type is one of the important characteristics of the soils generated from post-mining land. This parameter is strictly related to the type of the source rock and, in the case of post-mining areas, to the type of the dumped formation. The reaction of the analysed material was on the alkali level, in the range from 7.20 to $7.44\left(\mathrm{pH}_{\mathrm{H} 2 \mathrm{O}}\right)$. Moreover, the soil material showed relatively low salinity and specific electric conductivity (EC) values from 92 to $151 \mu \mathrm{S} \cdot \mathrm{cm}^{-1}$. The low content of nutrients (phosphorus, potassium, magnesium, nitrogen) also indicates the lack of the nutrition elements indispensable for growth and development (Table 2).

The most efficient plantings in field I were achieved in the following species: wild apple $M a$ lus domestica, cherry plum Prunus cerasifera, single-seeded hawthorn Crataegus monogyna and rosehip Rosa canina (over 90\%) (Fig. 1). Very low efficiency, only $20 \%$, was recorded in the case of common hazel Corylus avellana. Moreover, little differentiation of plantings efficiency in different months was observed for single-seeded hawthorn Crataegus monogyna and wild apple Malus domestica. These values amounted to over $95 \%$ in all months of the observation. Rowan Sorbus aucuparia and common pear Pyrus communis demonstrated considerable decrease of plantings efficiency. The trees of these species showed deterioration of health and, in consequence, their gradual elimination from the research fields. In the case of experimental field II, the most efficient plantings were those of rosehip Rosa canina and wild apple Malus domestica (Fig. 2). Similarly to the case described above, the lowest planting efficiency, only $15 \%$ in September, was recorded for common hazel Corylus avellana. An almost $20 \%$ decrease of common pear Pyrus communis, single-seeded hawthorn Crataegus monogyna and cherry plum Prunus cerasifera plantings efficiency was observed, versus the first month of the observation. Experimental field III showed similar characteristics to field II (Fig. 3). Rosehip Rosa canina, single-seed hawthorn Crataegus monogyna and wild apple

Table 1. The granulometric composition of the studied soils

\begin{tabular}{|c|c|c|c|c|c|c|c|}
\hline \multirow{2}{*}{$\begin{array}{l}\text { No. } \\
\text { of plots }\end{array}$} & \multirow{2}{*}{$\begin{array}{l}\text { Depth } \\
{[\mathrm{cm}]}\end{array}$} & \multicolumn{5}{|c|}{ Percentage content of granulometric fractions [mm] } & \multirow{2}{*}{$\begin{array}{c}\text { Granulometric } \\
\text { group }\end{array}$} \\
\hline & & $>2$ & $<2$ & $\Sigma>0.05$ & $\Sigma>0.002$ & $<0.002$ & \\
\hline $\mathrm{I}$ & $0-30$ & 81 & 19 & 50 & 32 & 18 & $\mathrm{~L}$ \\
\hline II & $0-30$ & 66 & 34 & 64 & 25 & 11 & $\mathrm{SL}$ \\
\hline III & $0-30$ & 11 & 89 & 60 & 15 & 25 & SCL \\
\hline
\end{tabular}

Granulometric group: SL - sandy loam, SCL - sandy clay loam, L - loam

Table 2. Physicochemical and chemical properties of the investigated soil

\begin{tabular}{|c|c|c|c|c|c|c|c|c|}
\hline \multirow{2}{*}{ No. of plots } & \multicolumn{2}{|c|}{$\mathrm{pH}[-]$} & \multirow{2}{*}{$\begin{array}{c}E C \\
{\left[\mu S \cdot \mathrm{cm}^{-1}\right]}\end{array}$} & $\mathrm{P}$ & $\mathrm{K}$ & $\mathrm{Mg}$ & TOC & $N_{t}$ \\
\hline & $\mathrm{H}_{2} \mathrm{O}$ & $\mathrm{KCl}$ & & \multicolumn{3}{|c|}{$\left[\mathrm{mg} \cdot 100 \mathrm{~g}^{-1}\right]$} & \multicolumn{2}{|c|}{$[\%]$} \\
\hline 1 & 7.20 & 6.28 & 92 & 2.2 & 5.6 & 2.1 & 0.66 & 0.0175 \\
\hline II & 7.44 & 7.24 & 151 & 1.7 & 9.4 & 3.4 & 1.69 & 0.0147 \\
\hline III & 7.38 & 7.14 & 123 & 1.1 & 3.4 & 1.8 & 2.11 & 0.0049 \\
\hline
\end{tabular}




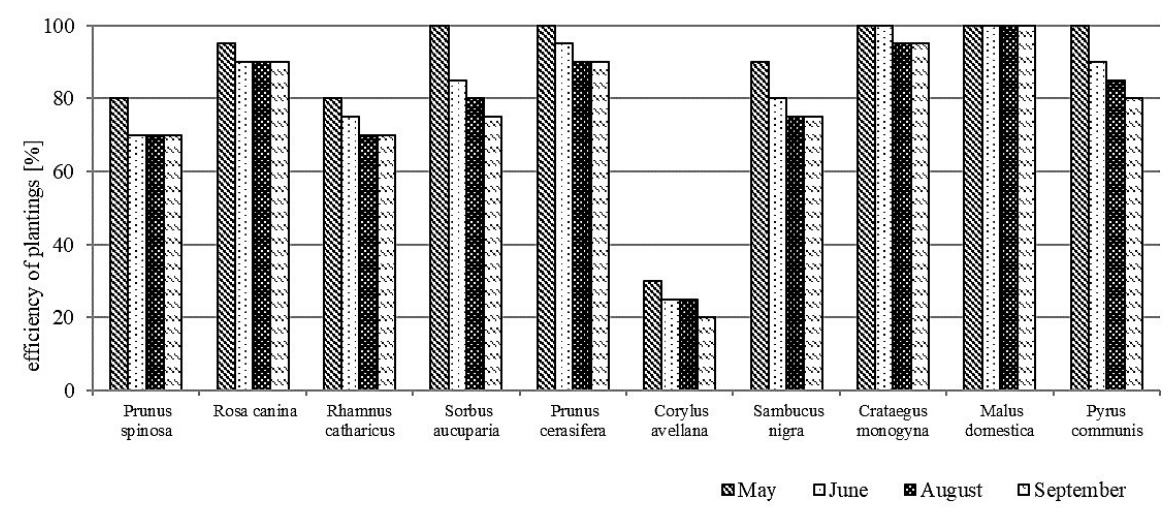

Figure 1. Efficiency of plantings introduced on the surface number I [\%]

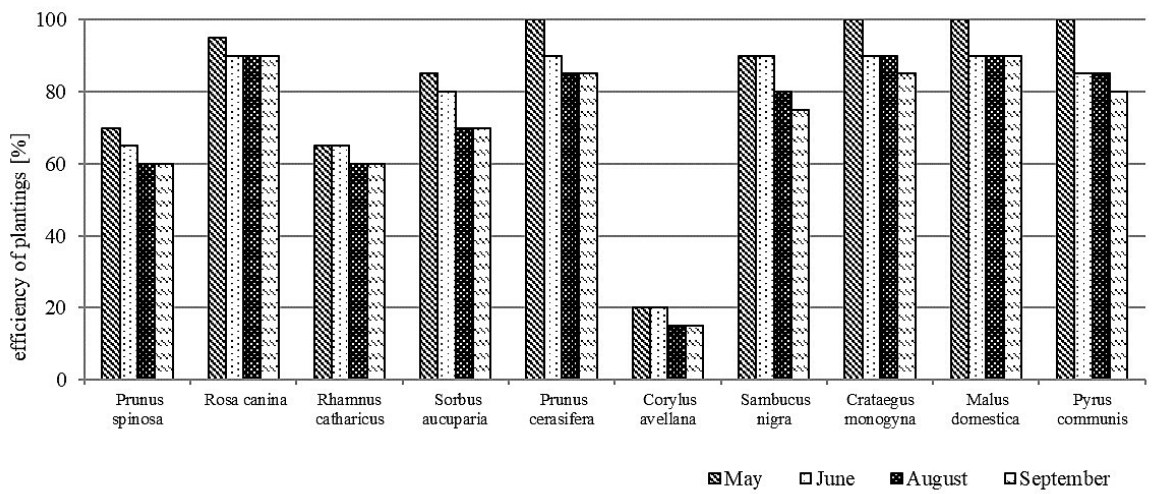

Figure 2. Efficiency of plantings introduced on the surface number II [\%]

Malus domestica showed the highest plantings efficiency. In the case of common hazel Corylus avellana, the plantings efficiency was very low, only $15 \%$. The analysed trees and bushes, such as rowan Sorbus aucuparia, sloe Prunus spinosa and common hazel Corylus avellana showed a considerable number of eliminated plants during each month of monitoring.

Certain correlations were observed during the assessment of the health condition of the fruitbearing trees and bushes plantings. The dominance of the species with damages from 5 to $15 \%$ was observed in field I and III, whereas a considerable proportion of trees and bushes with damages from 15-25\% were observed in field II (Fig. 4).

\section{DISCUSSION}

The reclamation works in the "Górażdże" limestone pit currently under way and aiming at afforestation have encountered a number of problems. The issues include, among others, a large number of eliminated plantings as well as a very slow growth caused by difficult soil conditions [Kasprzyk 2009; Krzaklewski and Mikłaszewski 1996]. The land generated during the technical reclamation contains initial soils with high neutral or low alkaline reaction, low content of organic carbon, phosphorus, nitrogen, potassium and macroelements, i.e. copper and zinc, unfavourable proportion of carbon to nitrogen, which does not favour the growth and development of forest trees [Szafrański and Stachowski 2000]. The efficiency of restoring the usefulness of these areas depends on, among others, a proper selection of tree-form plants as well as the plantings method, taking into consideration the plants mix type and characteristics [Khater and Arnaud 2007; Kopcewicz and Lewak 2012].

The currently introduced plantings based on Scots pine Pinus silvestris monoculture can create improved biocenosis by adding small areas with fruit-bearing trees and bushes. These areas may be separated, dispersed all over the reclaimed pit area or aligned along technological roads, which divide sectors of the dump or footwalls. The carried out research demonstrated both the large 


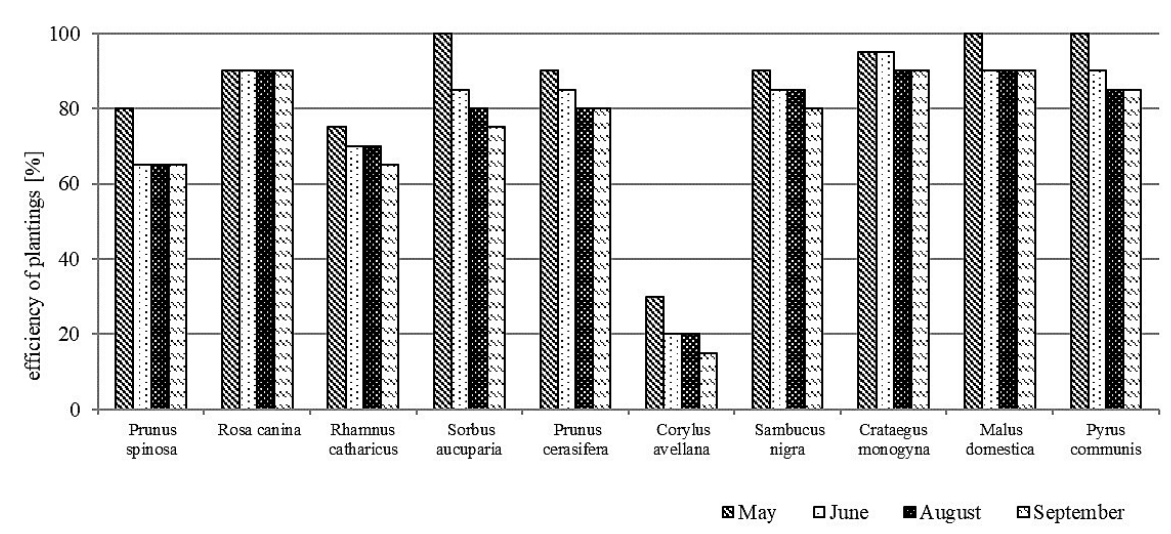

Figure 3. Efficiency of plantings introduced on the surface number III [\%]

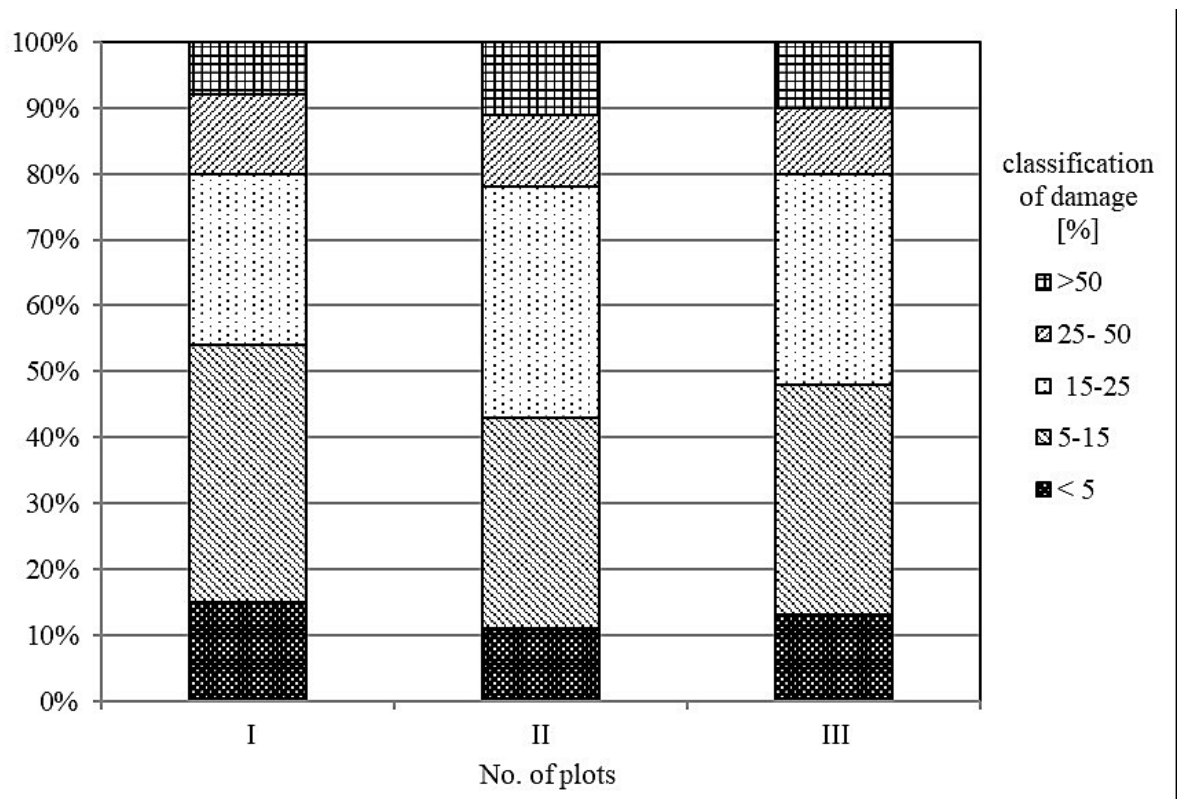

Figure 4. Evaluation of the health condition of plantings introduced on the investigated areas [\%]

efficiency of plantings as well as the good health of such plants as wild apple Malus domestica, common pear Pyrus communis, rosehip Rosa cani$n a$, sloe Prunus spinosa and single-seeded hawthorn Crataegus monogyna. The settlements with these plants will be feeding spots and shelters for small forest animals and, during the blooming seasons, for insects and birds, in this way increasing biological diversity of the degraded landscape of the open pit.

\section{CONCLUSIONS}

1. Realisation of the research by introducing small areas with fruit-bearing trees and bushes plantings will influence the flora and fauna biodiversity in the reclaimed area of the
"Górażdże" limestone quarry. This will result in the increased natural and recreational properties of the discussed area.

2. Considerably high efficiency of the planted trees and bushes, regardless of the settlement conditions, was observed during the carried out research. Wild apple Malus domestica, common pear Pyrus communis, rosehip Rosa canina, sloe Prunus spinosa and single-seeded hawthorn Crataegus monogyna demonstrated the best health conditions during the whole vegetation period. This indicates usefulness of these plants in biological reclamation programs (replacing typical forest plants), in particular in the areas (settlements) with poor soil conditions.

3. Using biocenotic plants plantings will reduce the costs of reclamation stages, which is a 
benefit to the pit owners, as well as increase the ecological potential of the new biotope generated during strong anthropogenic pressure. The introduction of fruit-bearing trees and bushes is especially recommended along technical roads and in the vicinity of the pit footwalls.

4. The experimental works carried out in the "Górażdże" limestone quarry may be an example of optimisation of the reclamation processes realised in other limestone pits.

\section{REFERENCES}

1. Baran S., Turski R. 1996. Degradation, reclamation and soils protection (in Polish). Akademia Rolnicza. Lublin.

2. Dulewski J, Madej B. 2002. The state and work pro-ecological activities in mining. J. Ecol Engine, 6, 187-194.

3. Karczewska A. 2008. Soil protection and reclamation of degraded areas (in Polish). Wrocław University of Environmental and Life Science.

4. Kasprzyk P. 2009. Directions of reclamation in opencast mining. The Problems of Landscape Ecology, XXIV, 7-15.

5. Khater C., Arnaud M. 2007. Application of restoration ecology principles to the practice of limestone quarry rehabilitation in Lebanon. Lebanese Science Journal, 8(1),19-28.

6. Kopcewicz J., Lewak S. 2012. Plant physiology (in Polish). PWN, Warszawa.
7. Krzaklewski W, Mikłaszewski A. 1996. Reclamation of overburden dumps in brown coal mining in Poland. Scientific Papers of the Institute of Mining of the Wrocław University of Technology, $79,215-218$.

8. Krzaklewski W. 2017. The basics of forest reclamation (in Polish). Kraków.

9. Krzaklewski W., Pietrzykowski M. 2007. Site classification in post-mining areas reclaimed for forestry use with special focus on the phytosociological-soil method. Sylwan, 1, 51-57.

10. Mapa Sozologiczna Polski, arkusz Tarnow Opolski 4, woj. opolskie, skala 1:50000. 1996. Glowny Geodeta Kraju, Warszawa.

11. Particle size distribution and textural classes of soils and mineral materials - classification of Polish Society of Soil Science 2008 (in Polish). Soil Sci. Ann., 60(2),5-16.

12. Pietrzykowski M. 2008. Soil and plant communities development and ecological effectiveness of reclamation on a sand mine cast. J. For. Sci., 54(12), 554-565.

13. Strzyszcz Z, Harabin Z. 2004. Reclamation and biological management of coal mining wastes taking into special consideration central heaps, Works \&Studies IPIŚ PAN, 61.

14. Strzyszcz Z. 2003. Application of mineral fertilizers for forest reclamation of mine spoils in Poland. Arch. Environ. Protect., 29(4), 25-40.

15. Strzyszcz Z. 1995. Soil-free method of biological reclamation of waste pitches of hard coal mining (in Polish). Wiadomości Górnicze, 6, 253-258.

16. Szafrański Cz., Stachowski P. 2000. Physical, chemical and soil-forming properties from post-mining soils. Roczniki AR, Poznań, CCCXVII, 377-390. 